International Journal of Social Science and Economic Research

ISSN: 2455-8834

Volume:06, Issue:05 "May 2021"

\title{
AGRO- ECOTOURISM SUSTAINABLE DEVELOPMENT BUSINESS MODEL FOR GOA
}

\author{
Chittaranjandas Vinayak Devulkar \\ Ph.D. Scholar, Dr. Dada Vaidya College of Education, Ponda Goa \\ Asst. Science Teacher, Vivekananda Vidyalaya, Shirshire Bori-Ponda Goa \\ DOI: 10.46609/IJSSER.2021.v06i05.006 URL: https://doi.org/10.46609/IJSSER.2021.v06i05.006
}

\begin{abstract}
Sustainable Development is receiving growing attention from academicians, industry representatives and policy-makers (e.g.,United Nations, 2016; European Union, 2014 Elkington (1997), using the so-called "triple bottom line," suggests that equal consideration should be given to financial, environmental, and social dimensions when making business model and policy decisions. Future Shock written by the famed futurist Alvin Toffler, in which he defined the term 'future shock' as 'too much change in too short a period of time'. In the Covid 19 pandemic too, it is the ability to cope with change, cope with the new normal, Toffler said back then 50 years ago that 'copability' will be more important in the future than 'capability' in this pandemic Some will succeed, some will struggle, some will perish. Survival of the fittest is the new mantra of this pandemic. The COVID-19 lockdowns in the State and the country has actually become a game-changer for the agriculture sector, almost in all the taluka villages of Goa. Farmers, who had given up cultivation for decades are moving back to the occupation. In all likelihood, nature, wildlife, traditional occupation like agriculture, fishing will be preferred over beaches and temples \& churches in the months ahead. So, the hills, trecking, bird watching, wild life photography, mountain terrain cycling, meditation in wild life reserves, water falls, lakes and slightly isolated locations like village tourism i.e.Agro-Eco tourism will win over crowded favourites by our domestic tourist if not international in our beautiful Goa in this pandemic. Goa State Agriculture Department has reported more than five-fold increase in demand for vegetables \& sale of seeds during this season. In fact the Goa Govt. should take initiative to tie up local bodies like Gram panchayat by involving local community and important departments like Agriculture, Tourism, Fishery, Biodiversity Cell with the passed out unemployed students of two Agricultural colleges one from savoi verem \& the other from Quepem for promoting Agro eco-tourism in villages\& involve our unemployed youths \& helpless Goan's in providing sustainable self-employment in this pandemic situation.
\end{abstract}

Key words: Sustainable development, Agro-Eco tourism, self-employment, Copability, Future shock 
International Journal of Social Science and Economic Research

ISSN: 2455-8834

Volume:06, Issue:05 "May 2021"

\section{Introduction}

Tourism being Goa's biggest revenue-earner, a lot of people have left their traditional occupations like farming and fishing and joined the tourism industry, becoming taxi operators, small hotel owners, shack owners, water sports operators and guesthouse owners before COVID pandemic, But with tourism now at a standstill due to coronavirus pandemic, these people are relying on their savings or going back to these traditional occupations like Agriculture \& fishing to earn their living which is still uncertain.

With Tourism \& Mining activities are at standstill during this pandemic, a ray of hope is seen from Agriculture Eco-tourism as an alternative \& sustainable option for the helpless people of Goa, However Govt. should look at this perspective in a holistic way so that Local community participation with the local panchayat members should be involved with the decision making at policy framing level so that the sustained \& regular benefits of the new Agro eco-tourism business model reaches to the grass root level in this pandemic. .

The Goa government had set up a task force to recommend an economic revival plan for each village that is being anchored by the Goa Institute of Public Administration and Rural Development and the Directorate of Higher Education However, there are challenges being faced by the local community due to lack of support from local panchayat bodies.In an initial document the committee has suggested all panchayats to identify potential activities within the village which can provide livelihood to the people involved in agriculture and allied activities, horticulture, poultry, dairy, fishing and reviving micro and small scale industries besides traditional livelihood options like artisans and a plan to process and market the products. It is high time that this should be put in to practice by Government at ground level by involving local community.

People of Goa are ecologically literate, however they should be made aware about introduction of this Agro eco-tourism model at grassroots level by conducting webinars/seminars/workshops. This may need prolonged and widespread community sensitization movement but it is the need of the hour. It may be considered as a new mantra of the Govt. for the sustainable development of Goa.

Agro-Eco tourism Business Model chain: Forest Department, Agriculture Department, Tourism Department, Fishery Department, Biodiversity cell, Panchayat, Local community, Tourist.

Tourism Department: Processes involved

1. Submitting the business proposal to tourism department with terms \& conditions with guidelines. 
International Journal of Social Science and Economic Research

ISSN: 2455-8834

Volume:06, Issue:05 "May 2021"

2. Expertise, know how \& infrastructure that can be availed from the tourism dept. For the contract period.

3. Signing MoU with the dept. to track the type of tourist flow in different hotels/cottages/sanctuaries so also their comments on stay in Goa to be registered for improvement.

4. Coordinating \& liasoning with the tourism department. For the regular update on various events.

5. Identifying \& training local youths as tourist guide for employment

Forest Department: Processes involved

1. Signing an MOU with the Forest dept. to heir \& develop an forest area as " Goa's Biodiversity Resource center " with Tourist stay cottages, dormitories for student stay, research areas in wildlife, food court, forest village, studios depicting Goa's biodiversity \& important Goa's personalities with their pictures Contribution in the field of environment. Conservation (wildlife photographer, Herpetologist, Anthropologist, entomologist, Archeologist Etc.) Life of forest dwellers, hunters\& gatherers. Devrais \& its imp.

2. MOU for Erecting signage, boards \& hoardings of State animal, state bird, \& state trees at imp. Railway station, airport \& bus stand with message of saving them.

3. Training local youths to be forest guides to take trips for e.g. at Katlyachi mauli, Carambolim lake, Mardangad in Ponda, Bondla WLS, Butterfly park in cotigao etc.

4. To develop some of the hills/springs/waterfalls in the village as model ecotourism hill stations so as to involve the local community in establishing their business by tapping local talent.

5. Identifying local craftsmen/artisans like carpenter, florist, potter, sculptor, artist etc.\& involving them in this project for their sustainance.

\section{Agriculture Department: Processes involved}

1. Identifying the progressive farmers of various Talukawise groups practicing Organic farming \& arranging visits of tourist to their farm for studying agriculture as alternative $\&$ sustainable source of income.

2. Developing an Ideal Goan's agriculture organic farm village showcasing Kulagar \& multicroping system of local indigenous varieties of fruits \& vegetables grown in 
International Journal of Social Science and Economic Research

ISSN: 2455-8834

Volume:06, Issue:05 "May 2021"

different seasons with an outlet to sell the freshly grown fruits \& vegetables. It could also have a museum showing various traditional agricultural tools \& equipment's used by Goan's farmers also the "Seed lab" \& showcasing the different Traditional seeds \& Insect pest of specific plants like Mango stem borer, Teamosquito, army worm etc

3. Installing Small boards explaining the diffent processes involved in agriculture like ploughing, harrowing, drilling, weeding, irrigation, harvesting etc.

4. Promoting youngsters to take up start up business in Agriculture by depicting small documentaries of successful Goan's farmers in a studio.eg. Strawberry cultivation by selfhelp group at Netravali in Sanguem Taluka.Cabbage cultivation by Gawas family at Dabal in Sanguem.

5. Highlighting "Kumeri cultivation" as lesser known but important agriculture practice followed by the farmers of Ponda \& Sattari along the Mhadei River promote them with special scheme.

6. Bringing Goan traditional flower cultivator \& seller under our banner by providing them platform just as Horticulture Corporation Of Goa for promoting local traditional flowers.

7. Developing Shevanti(Aster), Mogri(Jai)\&Aboli(Crossandra) plots to show important flowers of Goa in maintaining tradition, culture \& biodiversity of Goa.

8. Identify the passed out unemployed youth of Goa from Agriculture College\& involve them in this project for employment.

\section{Processes involved with Core Committees \& Technology Partners:}

1. Identifying Technology partners

2. Roles \& responsibility, contract period with terms \& conditions of technology partners

3. Time table of monthly meetings \& conference

4. Creating whatsup group for webinar/zoom/telegram for discussion

5. Regular coordination with the technology partner with one coordinator from core group

6. Analysis of the feedback for improvement

\section{A) Core Departments involved:}

1) Forest Dept.

2). Agriculture Dept.

3). Tourism Dept.

4). Fishery Dept. 
5) Biodiversity cell

6) Local Panchayat

\section{B) Nodal Committees:}

1). Ministerial level committee

2). BDO/Admin officer

3). Panchayat level local committee

\section{C) Business model partners:}

1). Dedicated Technology partners

2). Media partners

3). Dedicated knowledge partners

4). Legal experts

5). Panchayat representative

6). Liasoning person

7). Merchandise partner

\section{Guiding principles of sustainable development:}

For better implementation of the agro ecotourism model for sustainability Government should strictly enforce the following guiding principles that the Tourism is for Goa, Goa is not for Tourism. Tourism should have ethics, without ethical foundation it is exploitation and sin. Centralized model of tourism planning destroys ecology and environment hence Decentralized; people oriented micro level planning should be promoted for sustainable tourism. All tourism products are sourced and are subsidized by nature-directly or indirectly. Tourists are to be treated as participants and partners not as just passive consumers, guests and travellers in ensuring environmental protection.

The key players in the Agro eco-tourism sustainable development business model are the Core government departments, Nodal committees, Business model partners and local authorities, the visitors and the local community. Each one of them has to be sensitive to the local traditions \& environmental conditions and follow a set of guidelines for the successful development of agro eco-tourism business model.

The government of Goa should implement the following guidelines: 


\section{International Journal of Social Science and Economic Research}

ISSN: $2455-8834$

Volume:06, Issue:05 "May 2021"

1) The management plan for each area proposed for agro eco-tourism should be prepared through professional landscape architects and rural planners and in consultation with the local community as well as other directly concerned. 2) To avoid intersectoral and interstate conflicts, integrated planning should be adopted for e.g. The Dudhsagar falls has its origin in Karnataka and is formed by the union of river Katla and Palna. At the same time Netravali in Sanguem and Cotigoa in Canacona share their borders with Karnataka and therefore integrated planning between the two states must be achieved 3) The architectural planning for agro eco-tourism centres should include controlled access points and cabins, roads, self-guided nature trails, Accessible Transportation options, interpretation centres signs, observation towers, adequate lodging and food facilities, water points, waste disposal facility etc. 4) Structures depicting pollution, anaesthetic values and non-compatible architecture should be 7) Specify environmental, physical and social carrying capacities of the area to be developed to limit development activities 8) Ensure continuous monitoring of adverse effect of tourism activities and initiate suitable corrective measures beforehand 9) Recognise and award quality labels to eco-tourism operators 10) Provide visitor information and interpretation services covering particularly i) what to see ii) how to see iii) how to behave in the developed area 11) Prepare and widely distribute codes of conduct to all visitors 12) Launch training programmes in all the departments involved on agro eco-tourism sustainable development model to sensitise \& make aware about the new concept by involving general public.

\section{Conclusion}

With Tourism, and Mining business which were the backbone of Goa's economy came to a standstill due to pandemic Goa has to rethink on alternative source of livelihood with so much of uncertainty faced during this one year. Inspite of being in Green zone when majority of our states were struggling in red zone \& with our neighbouring state KarnatakaIn Red zone due to COVID pandemic Goa had to transport tonnes of vegetables\& other basic necessities from Belgaum, and which was one of the reason of increasing corona positive cases in Goa. The youths of Goa need to change their attitude of depending on other states for our basic food requirement especially during such pandemic crises. However, Goa \& Goan's need sustainable development in Agriculture \& Tourism, we need to bring new concept of Agro eco-tourism model for our local traditional farmers, fishermen's community \& tourist making a viable \& sustainable model. The Goa govt.should take this opportunity by realising the pulse of the people by taking community participation \& prepare a draft of Business model given above of bringing Agriculture, Tourism, Forest Department \& fishery department together for sustaining unemployed youths \& helpless people of pandemic Goa who have lost their jobs due to stoppage of illegal mining, Tourism \& pandemic. Goa's Local Communities are artistic \& creative and are entitled to be part of this project, we need to promote this potential in planning Agro Eco tourism products and services 
International Journal of Social Science and Economic Research

ISSN: 2455-8834

Volume:06, Issue:05 "May 2021"

among Goan's."Sushegadibility" Sushegad attitude of Goan's should be replaced with Sustainability attitude so that it can ensure sustainability of participatory, ethical tourism with environmental conservation, as 'copability' will be more important in the future than 'capability' which we have experienced in this pandemic. As survival of the fittest is the new mantra of this pandemic people who do any business with health \& safety will succeed, people who play with safety \& health will struggle, people who don't like discipline in health \& safety will perish. Surplus wealth created from this model should be equally distributed among all the partners in the chain \& justice to be given for all.

\section{References}

1. Afonso, A; Rodrigues, T (1994). Tourism in Goa, Socio-economic impact-Manuscript Report 2, Institute of Social Sciences, New Delhi, pg. 25

2. Alvares, C. 1993. "Fish, Curry and Rice: A Citizen's Report on the State of the Goan Environment." Eco forum. Goa.

3. Andersen, David L. 1992. Creating a Framework for Responsible Design of Ecotourism Facilities.

4. Bruno Silvestre,2018, Innovations for sustainable development: Moving towards a sustainable future, Journal of cleaner production.

5. D'Amore, Lou. 1992. Ethics and Guidelines for Sustainable Tourism.

6. Denman, Richard. 1992. Fostering Ecotourism Enterprises in Local Communities.

7. Dodge, Kay. 1992. The Myths, Magic, and Money: Ecotourism - Models to Enhance the Use and Management of Protected Areas.

8. Edington, J. and A. 1986. Ecology, Recreation and Tourism. Cambridge University Press, Cambridge, UK.

9. Naik, S and Kamat, N, 2001Meeting on Goa Tourism Policy Organized by the Centre for Responsible Tourism (CRT) 16th - 17th February, 2013, Caritas Holiday Home, St Inez, Panjim and Sustainable ecotourism planning in Goa

10. The Navhind Times. 1997. "Sea Turtles on the Run as Humans Take over Beaches." February 20, p. 1. 